\title{
Spontaneous testicular regression in collared lemmings (Dicrostonyx groenlandicus) exposed to prolonged long photoperiod
}

\author{
B. A. Gower*, T. R. Nagy* and M. H. Stetson \\ Department of Biological Sciences, University of Delaware, Newark, DE 19716, USA
}

\begin{abstract}
Reproductive maturation and attainment of maximal gonadal size in collared lemmings (Dicrostonyx groenlandicus) is facilitated by transfer from a short photoperiod ( $8 \mathrm{~h}$ light:16 h dark) to a long photoperiod ( $22 \mathrm{~h}$ light: $2 \mathrm{~h}$ dark). However, reproductive maturation in lemmings born in $22 \mathrm{~h}$ light: $2 \mathrm{~h}$ dark is impeded by exposure to the natal photoperiod of $22 \mathrm{~h}$ light: $2 \mathrm{~h}$ dark. Data from adult lemmings suggest that prolonged exposure to a long photoperiod of $20 \mathrm{~h}$ light: $4 \mathrm{~h}$ dark results in gonadal regression. The present experiments were conducted to test the hypothesis that adult lemmings exposed to a prolonged long photoperiod undergo testicular regression. Male collared lemmings were transferred at weaning (19 days of age) from the natal photoperiod of $8 \mathrm{~h}$ light: $16 \mathrm{~h}$ dark to one of two long photoperiods: $22 \mathrm{~h}$ light: $2 \mathrm{~h}$ dark or $24 \mathrm{~h}$ light:0 h dark (constant light). Gonadal mass was maximal in both groups 10 weeks after weaning. However, 20 weeks after weaning, gonadal mass in both groups was low (relative to that at 10 weeks), suggesting that regression had occurred. When testes mass was maximal 10 weeks after weaning, animals were transferred in groups from $22 \mathrm{~h}$ light: $2 \mathrm{~h}$ dark to one of several shorter photoperiods: $20 \mathrm{~h}$ light: $4 \mathrm{~h}$ dark, $18 \mathrm{~h}$ light: $6 \mathrm{~h}$ dark, $16 \mathrm{~h}$ light: $8 \mathrm{~h}$ dark, or $8 \mathrm{~h}$ light:16 h dark. Testes mass 20 weeks after weaning was greatest, that is, not different from maximal, in animals from the $20 \mathrm{~h}$ light: $4 \mathrm{~h}$ dark and $18 \mathrm{~h}$ light: $6 \mathrm{~h}$ dark groups, intermediate in animals from the $16 \mathrm{~h}$ light: $8 \mathrm{~h}$ dark group, and low in animals from the $8 \mathrm{~h}$ light:16 $\mathrm{h}$ dark group. These observations indicate that transfer from $22 \mathrm{~h}$ light: $2 \mathrm{~h}$ dark to a slightly shorter photoperiod permits maintenance of gonadal size, but transfer to a short photoperiod causes testicular regression. Body weight, bifid claw width and pelage colour did not change during spontaneous gonadal regression in animals housed in a long photoperiod for 20 weeks. These results suggest that prolonged exposure to an unchanging long photoperiod causes spontaneous testicular regression, and that photoperiod regulates reproductive and somatic parameters independently.
\end{abstract}

\section{Introduction}

The Greenland or Northern collared lemming shows an atypical reproductive response to photoperiod compared with rodents from temperate latitudes. Although long daylength is stimulatory to gonadal growth in collared lemmings and many temperate zone rodents (Steinlechner and Niklowitz, 1992), expression of this effect in the collared lemming requires prior exposure to short daylengths (Nagy et al., 1993a; Gower et al., 1997). Unlike temperate zone rodents, collared lemmings mature slowly when raised in a chronic and unchanging long photoperiod. Maturation of long day-born lemmings can be enhanced by transfer to a short photoperiod, but the testicular mass attained under these circumstances is not maximal. These observations suggest that in collared lemmings photoperiod

\footnotetext{
*Present address: Department of Nutrition Sciences, Division of Physiology and Metabolism, University of Alabama at Birmingham, Birmingham, AL 35294-3360, USA
}

Received 10 October 1997. history has an important effect on maturation, and long days impart both stimulatory and inhibitory information.

The effect of photoperiod history on the reproductive response to daylength has been observed in other photoperiod-responsive animals. In some cases, the failure to respond to a given photoperiod as predicted has been termed refractoriness. Certain rodents become refractory to the inhibitory effect of short daylength on gonadal size, exhibiting spontaneous gonadal recrudescence after a given period of suppression (Zucker et al., 1980). In contrast, certain bird species become refractory to the stimulatory effect of long daylength on gonadal size, showing spontaneous gonadal regression during long days (Nicholls et al., 1988). In addition, sheep become refractory to the stimulatory effect of short days on reproductive function (Nicholls et al., 1988). Although the term refractory has been widely used to describe these and other observations in which a change in response to a given photoperiodic regimen has occurred, use of this term does not imply physiological homology (Nicholls et al., 1988). 
Limited data suggest that collared lemmings, unlike other photoperiodic rodents, display refractoriness to the stimulatory effect of long days on the reproductive system. Nagy (1993) reported that the testes of animals born in $16 \mathrm{~h}$ light: $8 \mathrm{~h}$ dark and housed in $20 \mathrm{~h}$ light: $4 \mathrm{~h}$ dark for 148 days were smaller than those of similarly treated animals housed in $20 \mathrm{~h}$ light: $4 \mathrm{~h}$ dark for 69 days, suggesting that testicular regression occurred in the former group. Gonadal growth of males born in the normally inhibitory photoperiod of $22 \mathrm{~h}$ light: $2 \mathrm{~h}$ dark is stimulated by this photoperiod if animals are exposed transiently to $8 \mathrm{~h}$ light:16 $\mathrm{h}$ dark (Gower et al., 1997). This latter observation suggests that males born in $22 \mathrm{~h}$ light: $2 \mathrm{~h}$ dark are refractory, that is, unable to respond, to the stimulatory effect of long day on maturation, and that sensitivity to this stimulatory effect can be regained by a temporary exposure to short photoperiod. Similar observations have been made in spring-born starlings (Sturnus vularis) (Williams et al., 1989; McNaughton et al., 1992).

The present experiments were conducted to characterize the effect of photoperiod history on reproductive status in male collared lemmings. The specific hypothesis that prolonged exposure to a long photoperiod causes spontaneous testicular regression which is indicative of refractoriness to long days was tested. Two daylengths were used: (i) $22 \mathrm{~h}$ light: $2 \mathrm{~h}$ dark, a photoperiod that allows lemmings to maintain production of a daily rhythm of pineal melatonin (Gower et al., 1996), the hormone that transduces photoperiod information (Stetson and Watson-Whitmyre, 1984); and (ii) constant light (24 h light:0 h dark), a photoperiod that has been shown to inhibit melatonin production (Rudeen, 1977), but is normally experienced for 2.5 months of the year by collared lemmings living at $66^{\circ} \mathrm{N}$ latitude (Nautical Almanac Office, 1991). The response of somatic parameters (body weight, pelage colour and bifid claw width) to these photoperiod manipulations was also characterized.

\section{Materials and Methods}

\section{Animals}

Collared lemmings were obtained from the colony at the University of Delaware. The progenitors of the colony were trapped in 1985 in Igloolik, Northwest Territories $\left(69^{\circ} 23^{\prime} \mathrm{N}\right.$, $\left.81^{\circ} 50^{\prime} \mathrm{W}\right)$. Adult male and female lemmings were paired and transferred from $16 \mathrm{~h}$ light: $8 \mathrm{~h}$ dark to $8 \mathrm{~h}$ light: $16 \mathrm{~h}$ dark (short day) to produce animals for the present experiments. Offspring were weaned at 19 days of age and males were immediately entered into the experiments. Experimental animals were housed two or three per polypropylene cage $(38 \mathrm{~cm} \times 20 \mathrm{~cm} \times$ $15 \mathrm{~cm}$ ) and given food (ProLab Rabbit Diet, Agway, Syracuse, NY) and water ad libitum. The temperature was maintained at approximately $20^{\circ} \mathrm{C}$. For all photoperiods, lights were turned off at 20:00 h.

\section{Experiment 1}

Experiment I was conducted to determine whether the reproductive response of collared lemmings transferred from short daylength to $24 \mathrm{~h}$ light: $\mathrm{h}$ dark (constant light) is analogous to that observed after transfer from short daylength to $22 \mathrm{~h}$ light: $2 \mathrm{~h}$ dark. Constant light is the longest daylength collared lemmings are exposed to in their natural environment (Nautical Almanac Office, 1991).

At weaning, male lemmings were either transferred from $8 \mathrm{~h}$ light:16 h dark (short day) to $24 \mathrm{~h}$ light:0 h dark or were retained in short day conditions. After 10 weeks, half of the animals transferred to $24 \mathrm{~h}$ light:0 $\mathrm{h}$ dark were killed. The remaining animals were kept in $24 \mathrm{~h}$ light: $0 \mathrm{~h}$ dark for another 10 weeks and were then killed ( 20 weeks after weaning). There were at least eight animals in each group.

\section{Experiment 2}

Experiment 2 was conducted to examine the response of adult photostimulated lemmings to prolonged exposure to $22 \mathrm{~h}$ light: $2 \mathrm{~h}$ dark, and to a decrease in photoperiod. Some avian species show refractoriness to long days only after a slight decrease in daylength (to a shorter long day) (Nicholls et al., 1988). Therefore, collared lemmings were exposed both to static long day, and to decrements in photoperiod of several magnitudes

At weaning, male lemmings were transferred from $8 \mathrm{~h}$ light:16 h dark to $22 \mathrm{~h}$ light: $2 \mathrm{~h}$ dark. One group of animals was killed 10 weeks after weaning. The remaining animals were divided into five groups; one group remained in $22 \mathrm{~h}$ light: $2 \mathrm{~h}$ dark, and the rest were transferred to one of four shorter photoperiods: $20 \mathrm{~h}$ light: $4 \mathrm{~h}$ dark, $18 \mathrm{~h}$ light: $6 \mathrm{~h}$ dark, $16 \mathrm{~h}$ light: $8 \mathrm{~h}$ dark, or $8 \mathrm{~h}$ light: $16 \mathrm{~h}$ dark. These animals were killed 20 weeks after weaning. There were at least eight animals in each group.

\section{Measurements}

Carcasses were weighed to the nearest $0.1 \mathrm{~g}$; paired testes to the nearest $0.1 \mathrm{mg}$; and seminal vesicles to the nearest $1 \mathrm{mg}$ (after expression of fluid). Bifid claw width was measured at the base to the nearest $0.1 \mathrm{~mm}$ with vernier calipers. Pelage colour was rated on a scale of 1 to 5 (Maier and Feist, 1991), with 1 being the grey summer pelage and 5 being the white winter pelage.

\section{Statistical analyses}

Data from Expt I for paired testes mass, seminal vesicle mass, body weight, claw width, and pelage colour were analysed by two-way analysis of variance (ANOVA), with photoperiod and age as the main effects, and a least-squares means posthoc test.

Data from Expt 2 for the 10-week group were compared with those for the 20-week groups with a t test. Among the 20-week groups, means were compared with a one-way ANOVA and a least-squares means test.

ANOVAs and $t$ tests were conducted on log-transformed data. Data were back-transformed following analyses, and are reported as mean \pm SEM. For all tests, differences were considered significant if $P<0.05$. 


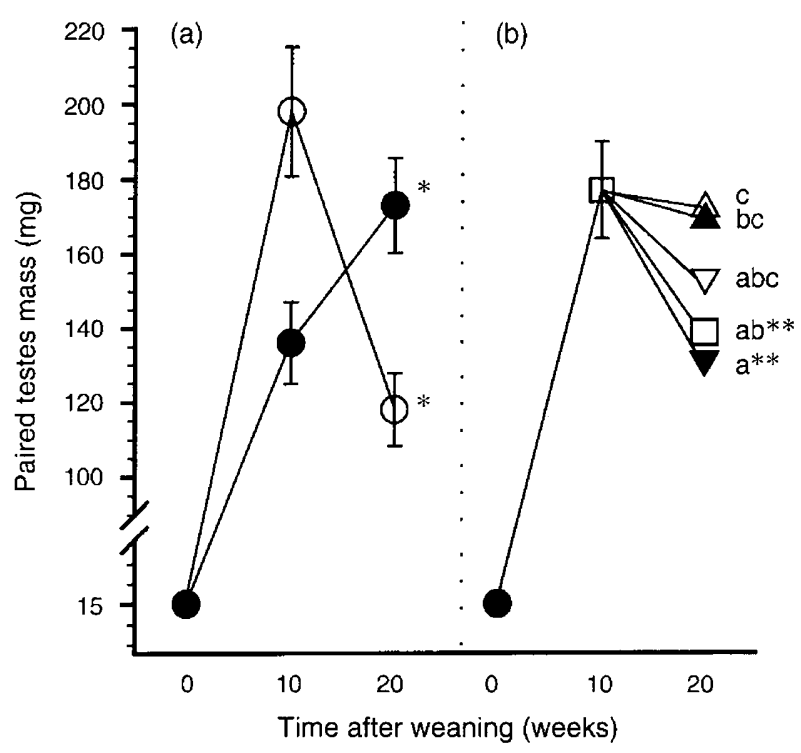

Fig. 1. (a) Testes mass in collared lemmings born in $8 \mathrm{~h}$ light: $16 \mathrm{~h}$ dark photoperiod and retained at weaning in (1) $8 \mathrm{~h}$ light:16 h dark photoperiod or transferred to (O) $24 \mathrm{~h}$ light:0 h dark. (b) Testes mass in collared lemmings born in $8 \mathrm{~h}$ light: $16 \mathrm{~h}$ dark photoperiod and transferred at weaning from (O) $8 \mathrm{~h}$ light:16 h dark to ( $\square) 22 \mathrm{~h}$ light: $2 \mathrm{~h}$ dark. Ten weeks after weaning animals were retained in $(\square)$

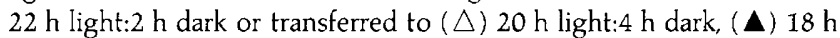
light: $6 \mathrm{~h}$ dark, $(\nabla) 16 \mathrm{~h}$ light: $8 \mathrm{~h}$ dark or $(\boldsymbol{\nabla}) 8 \mathrm{~h}$ light:16 h dark. * indicates values are significantly different within groups between 10 and 20 weeks. ${ }^{* *}$ indicates values are significantly different from the 10-week group ( $22 \mathrm{~h}$ light: $2 \mathrm{~h}$ dark, $P<0.05$ ). Different letters indicate significantly different means $(P<0.05)$. Error bars are omitted from $(b)$ for clarity. Testes mass at week $O$ (weaning) estimated from previous data (B. A. Gower, T. R. Nagy and M. H. Stetson, unpublished). Values are means \pm SEM.

\section{Results}

\section{Experiment 1}

Reproductive parameters. Paired testes mass was affected by the interaction of photoperiod and age $(P<0.001$, Fig.1a). Testes mass in the $24 \mathrm{~h}$ light:0 $\mathrm{h}$ dark group was greater 10 weeks after weaning than 20 weeks. In the $8 \mathrm{~h}$ light:16 h dark group, testes mass was greater 20 weeks after weaning than 10 weeks. Testes mass was not affected by photoperiod $(P=0.989)$ or by age $(P=0.089)$. The effect of the class variables on seminal vesicle mass was $P=0.056$ (model $P$ value, Fig. 2a). The effect of both photoperiod and age was $P=0.04$.

Somatic parameters. Body weight was affected by photoperiod $(P<0.001)$, but not by age $(P=0.40)$ or the interaction of photoperiod and age $(P=0.09$, Fig. 3a). Animals that remained in $8 \mathrm{~h}$ light: $16 \mathrm{~h}$ dark were larger at both time points than those that were transferred to $24 \mathrm{~h}$ light: $\mathrm{h}$ dark. Bifid claw width was influenced by photoperiod $(P<0.001)$, but not by age or the interaction of photoperiod and age $(P=0.27$ for both, Fig. 4a). Animals that remained in $8 \mathrm{~h}$ light: $16 \mathrm{~h}$ dark had larger claws at both time points than those that were transferred to $24 \mathrm{~h}$ light: $0 \mathrm{~h}$ dark. Pelage colour was affected by

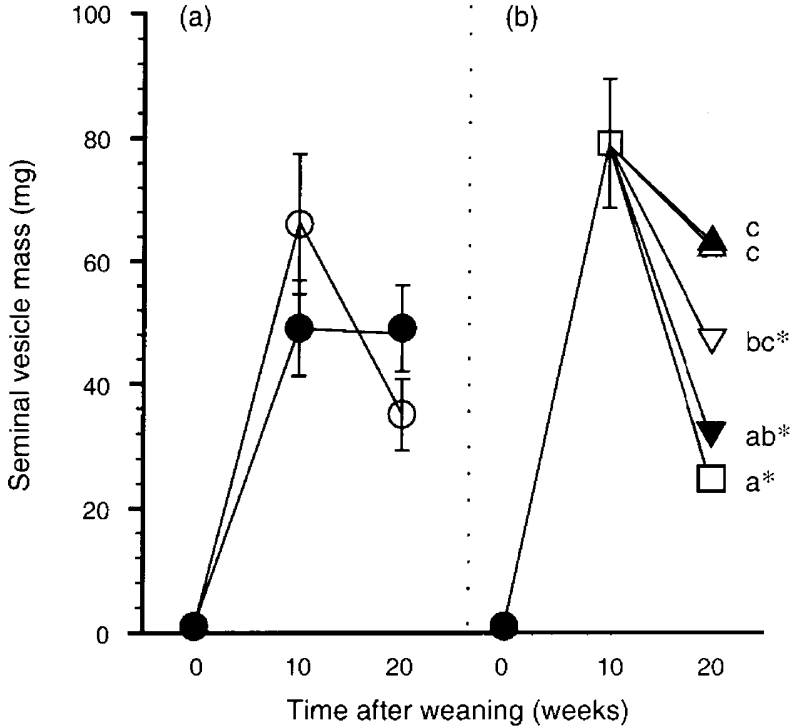

Fig. 2. (a) Seminal vesicle mass in collared lemmings born in $8 \mathrm{~h}$ light:16 h dark photoperiod and retained at weaning in $8 \mathrm{~h}$ light:16 h dark photoperiod or transferred to (O) $24 \mathrm{~h}$ light:0 h dark. (b) Seminal vesicle mass in collared lemmings born in $8 \mathrm{~h}$ light:16 h dark photoperiod and transferred at weaning from (O) $8 \mathrm{~h}$ light:16 $\mathrm{h}$ dark to ( $\square) 22 \mathrm{~h}$ light: $2 \mathrm{~h}$ dark. Ten weeks after weaning animals were retained in $(\square) 22 \mathrm{~h}$ light: $2 \mathrm{~h}$ dark or transferred to $(\triangle) 20 \mathrm{~h}$ light: $4 \mathrm{~h}$

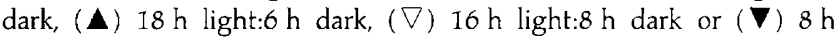
light:16 h dark. $*$ indicates values are significantly different from the 10 -week group ( $22 \mathrm{~h}$ light: $2 \mathrm{~h}$ dark, $P<0.05$ ). Different letters indicate significantly different means $(P<0.05)$. Error bars are omitted from (b) for clarity. Seminal vesicle mass at week 0 (weaning) estimated from previous data (B. A. Gower, T. R. Nagy and M. H. Stetson, unpublished). Values are means \pm SEM.

photoperiod, age $(P<0.001$ for both, Fig. $5 \mathrm{a})$, and the interaction of photoperiod and age $(P<0.05)$. Animals remaining in $8 \mathrm{~h}$ light:16 h dark were lighter in colour at both 10 and 20 weeks after weaning than those transferred to $24 \mathrm{~h}$ light: $\mathrm{O} \mathrm{h}$ dark.

\section{Experiment 2}

Reproductive parameters. Paired testes mass 20 weeks after weaning was lower in animals transferred to $8 \mathrm{~h}$ light: $16 \mathrm{~h}$ dark or remaining in $22 \mathrm{~h}$ light: $2 \mathrm{~h}$ dark compared with that 10 weeks after weaning (Fig. Ib). The testes from animals exposed to the other three photoperiods did not differ from those of the 10 -week group. Among the 20-week groups, testes in animals transferred to $20 \mathrm{~h}$ light: $4 \mathrm{~h}$ dark and $18 \mathrm{~h}$ light: $6 \mathrm{~h}$ dark were not significantly different, and were heavier than testes of animals in the $8 \mathrm{~h}$ light: $16 \mathrm{~h}$ dark group. The testes of animals in the $20 \mathrm{~h}$ light: $4 \mathrm{~h}$ dark group were larger than those of animals in the $22 \mathrm{~h}$ light: $2 \mathrm{~h}$ dark group, whereas those of the $18 \mathrm{~h}$ light: $6 \mathrm{~h}$ dark group were not $(P=0.06)$. The testes of animals in the $16 \mathrm{~h}$ light: $8 \mathrm{~h}$ dark group were not different in size from those of animals in any other 20-week group.

Seminal vesicle mass 20 weeks after weaning compared with that 10 weeks after weaning was lower in animals transferred to $8 \mathrm{~h}$ light:16 h dark or $16 \mathrm{~h}$ light: $8 \mathrm{~h}$ dark, and in animals remaining in $22 \mathrm{~h}$ light: $2 \mathrm{~h}$ dark $(P<0.001$ in all cases, Fig. $2 \mathrm{~b})$. 


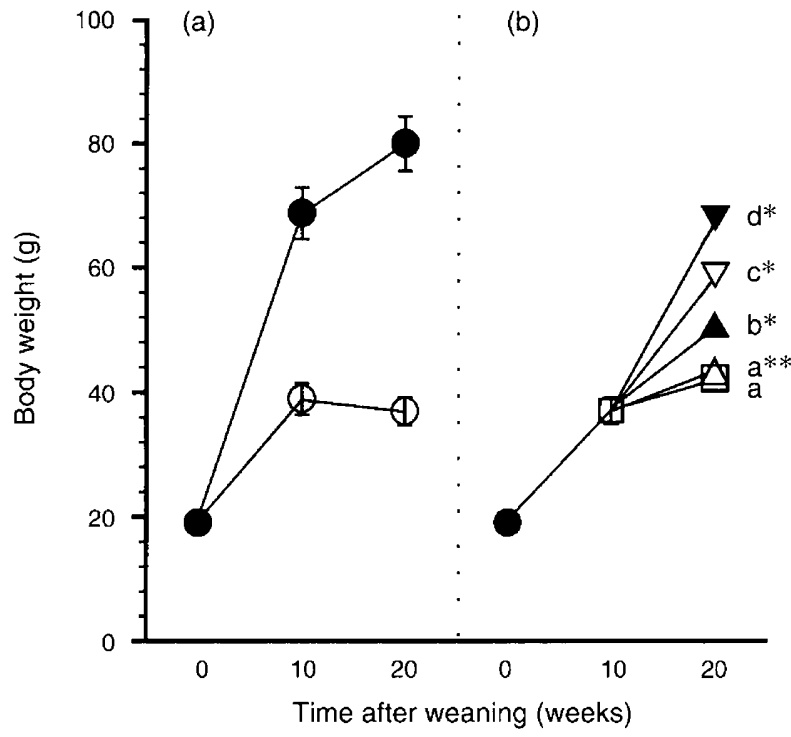

Fig. 3. (a) Body weight in collared lemmings born in $8 \mathrm{~h}$ light:16 h dark photoperiod and retained at weaning in (O) $8 \mathrm{~h}$ light:16 h dark photoperiod or transferred to (O) $24 \mathrm{~h}$ light:0 h dark. (b) Body weight in collared lemmings born in $8 \mathrm{~h}$ light: $16 \mathrm{~h}$ dark photoperiod and transferred at weaning from (-) $8 \mathrm{~h}$ light:16 h dark to ( $\square$ ) $22 \mathrm{~h}$ light: $2 \mathrm{~h}$ dark. Ten weeks after weaning animals were retained in ( $\square$ ) $22 \mathrm{~h}$ light: $2 \mathrm{~h}$ dark or transferred to $(\Delta) 20 \mathrm{~h}$ light: $4 \mathrm{~h}$ dark, $(\boldsymbol{A}) 18 \mathrm{~h}$ light: $6 \mathrm{~h}$ dark, $(\nabla) 16 \mathrm{~h}$ light: $8 \mathrm{~h}$ dark or $(\nabla) 8 \mathrm{~h}$ light:16 h dark. $*$ indicates values are significantly different from the 10-week group (22 h light: $2 \mathrm{~h}$ dark, $P<0.05$ ). ${ }^{* *}$ indicates values tend to differ from the 10-week group ( $22 \mathrm{~h}$ light: $2 \mathrm{~h}$ dark, $0.05<P<0.1$ ). Different letters indicate significantly different means $(P<0.05)$. Error bars are omitted from (b) for clarity. Body weight at week 0 (weaning) estimated from previous data (Gower et al., 1994). Values are means \pm SEM.

Among the 20-week groups, seminal vesicles of animals transferred to $20 \mathrm{~h}$ light: $4 \mathrm{~h}$ dark and $18 \mathrm{~h}$ light: $6 \mathrm{~h}$ dark were not significantly different $(P>0.05)$, and were heavier than seminal vesicles of animals in the $22 \mathrm{~h}$ light: $2 \mathrm{~h}$ dark $(P<0.001)$ and $8 \mathrm{~h}$ light:16 h dark $(P<0.01)$ groups. The seminal vesicles of animals in the $16 \mathrm{~h}$ light: $8 \mathrm{~h}$ dark group differed in mass from those of animals in the $22 \mathrm{~h}$ light: $2 \mathrm{~h}$ dark group $(P<0.01)$; those of animals in the $8 \mathrm{~h}$ light: $16 \mathrm{~h}$ dark and $22 \mathrm{~h}$ light: $2 \mathrm{~h}$ dark groups were not significantly different $(P>0.05)$.

Somatic parameters. Animals transferred to $8 \mathrm{~h}$ light: $16 \mathrm{~h}$ dark, $16 \mathrm{~h}$ light: $8 \mathrm{~h}$ dark, and $18 \mathrm{~h}$ light: $6 \mathrm{~h}$ dark had greater body weights compared with the 10-week group ( $P=0.07$ for the comparison with the $20 \mathrm{~h}$ light: $4 \mathrm{~h}$ dark group, Fig. 3b). At 20 weeks after weaning, animals in the $8 \mathrm{~h}$ light: $16 \mathrm{~h}$ dark group were heavier than animals in all other groups $(P<0.001$ versus $18 \mathrm{~h}$ light: $6 \mathrm{~h}$ dark, $20 \mathrm{~h}$ light: $4 \mathrm{~h}$ dark and $22 \mathrm{~h}$ light: $2 \mathrm{~h}$ dark; $P<0.05$ versus $16 \mathrm{~h}$ light: $8 \mathrm{~h}$ dark). The body weights of animals in $20 \mathrm{~h}$ light: $2 \mathrm{~h}$ dark and $22 \mathrm{~h}$ light: $2 \mathrm{~h}$ dark were not significantly different, but animals in these groups weighed less than animals in all other photoperiods $(P<0.001$ versus $8 \mathrm{~h}$ light: $16 \mathrm{~h}$ dark and $16 \mathrm{~h}$ light: $8 \mathrm{~h}$ dark; $P<0.05$ versus $18 \mathrm{~h}$

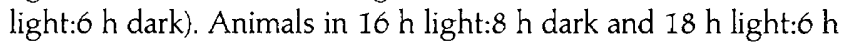
dark differed in body weight $(P<0.05)$.

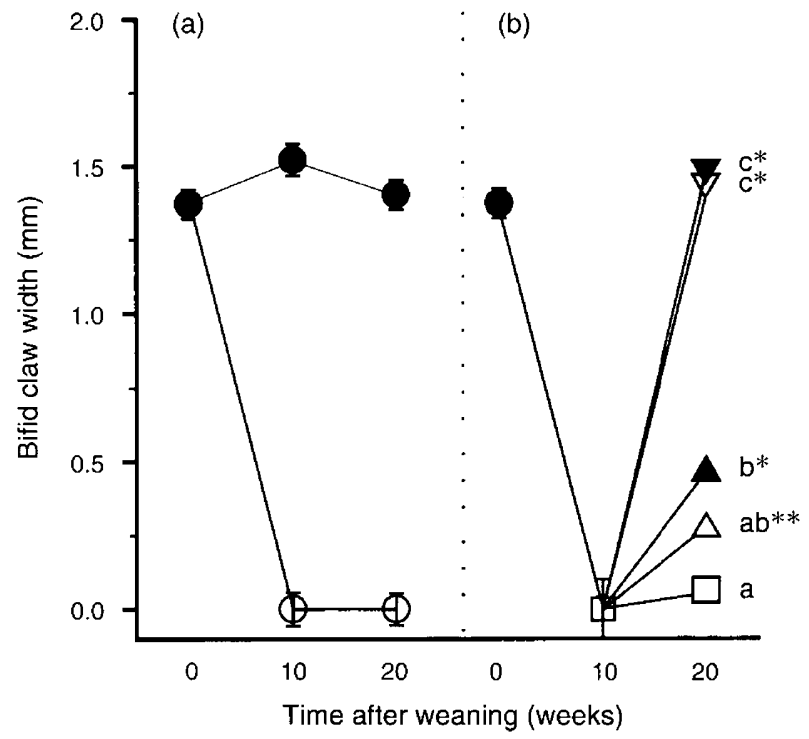

Fig. 4. (a) Bifid claw width in collared lemmings born in $8 \mathrm{~h}$ light: $16 \mathrm{~h}$ dark photoperiod and retained at weaning in (1) $8 \mathrm{~h}$ light:16 h dark photoperiod or transferred to (O) $24 \mathrm{~h}$ light:0 h dark. (b) Bifid claw width in collared lemmings born in $8 \mathrm{~h}$ light: $16 \mathrm{~h}$ dark photoperiod and transferred at weaning from (O) $8 \mathrm{~h}$ light:16 h dark to ( $\square) 22 \mathrm{~h}$ light: $2 \mathrm{~h}$ dark. Ten weeks after weaning animals were retained in $(\square)$ $22 \mathrm{~h}$ light: $2 \mathrm{~h}$ dark or transferred to $(\Delta) 20 \mathrm{~h}$ light: $4 \mathrm{~h}$ dark, $(\boldsymbol{\Delta}) 18 \mathrm{~h}$ light: $6 \mathrm{~h}$ dark, $(\nabla) 16 \mathrm{~h}$ light: $8 \mathrm{~h}$ dark or $(\boldsymbol{\nabla}) 8 \mathrm{~h}$ light:16 h dark. * indicates values are significantly different from the 10-week group ( $22 \mathrm{~h}$ light: $2 \mathrm{~h}$ dark, $P<0.05$ ). ${ }^{* *}$ indicates values tend to differ from the 10 -week group ( $22 \mathrm{~h}$ light: $2 \mathrm{~h}$ dark, $0.05<P<0.1$ ). Different letters indicate significantly different means $(P<0.05)$. Error bars are omitted from (b) for clarity. Claw width at week 0 (weaning) estimated from previous data (B. A. Gower, T. R. Nagy and M. H. Stetson, unpublished). Values are means \pm SEM.

The bifid claws of the $8 \mathrm{~h}$ light: $16 \mathrm{~h}$ dark, $16 \mathrm{~h}$ light: $8 \mathrm{~h}$ dark and $18 \mathrm{~h}$ light: $6 \mathrm{~h}$ dark groups were larger than those of the 10-week group $(P=0.07$ for the comparison with the $20 \mathrm{~h}$ light: $4 \mathrm{~h}$ dark group, Fig. $4 \mathrm{~b}$ ). At 20 weeks after weaning, bifid claws of animals in the $8 \mathrm{~h}$ light:16 h dark and $16 \mathrm{~h}$ light: $8 \mathrm{~h}$ dark groups were not significantly different, but the claws of animals in these two groups were larger compared with all other groups $(P<0.001)$. The claws of animals from the $18 \mathrm{~h}$ light: $6 \mathrm{~h}$ dark group differed from those of animals exposed to $22 \mathrm{~h}$ light: $2 \mathrm{~h}$ dark, but not from those of animals exposed to $20 \mathrm{~h}$ light: $4 \mathrm{~h}$ dark. The claws of animals in the $20 \mathrm{~h}$ light: $4 \mathrm{~h}$ dark and $22 \mathrm{~h}$ light: $2 \mathrm{~h}$ dark groups were not significantly different.

The pelage colour of animals transferred to $8 \mathrm{~h}$ light:16 h dark was significantly whiter, whereas that of animals transferred to $18 \mathrm{~h}$ light: $6 \mathrm{~h}$ dark and $20 \mathrm{~h}$ light: $4 \mathrm{~h}$ dark, or remaining in $22 \mathrm{~h}$ light: $2 \mathrm{~h}$ dark was significantly darker compared with the 10-week group (Fig. 5b). At 20 weeks after weaning, pelage colour did not differ among the $18 \mathrm{~h}$ light: $6 \mathrm{~h}$ dark, $20 \mathrm{~h}$ light: $4 \mathrm{~h}$ dark, and $22 \mathrm{~h}$ light: $2 \mathrm{~h}$ dark groups, but the animals in these groups were darker (lower colour rating) than in the $16 \mathrm{~h}$ light: $8 \mathrm{~h}$ dark and $8 \mathrm{~h}$ light:16 h dark groups $(P<0.001)$. There was also a significant difference in pelage colour between the $16 \mathrm{~h}$ light: $8 \mathrm{~h}$ dark and $8 \mathrm{~h}$ light: $16 \mathrm{~h}$ dark groups $(P<0.001)$. 


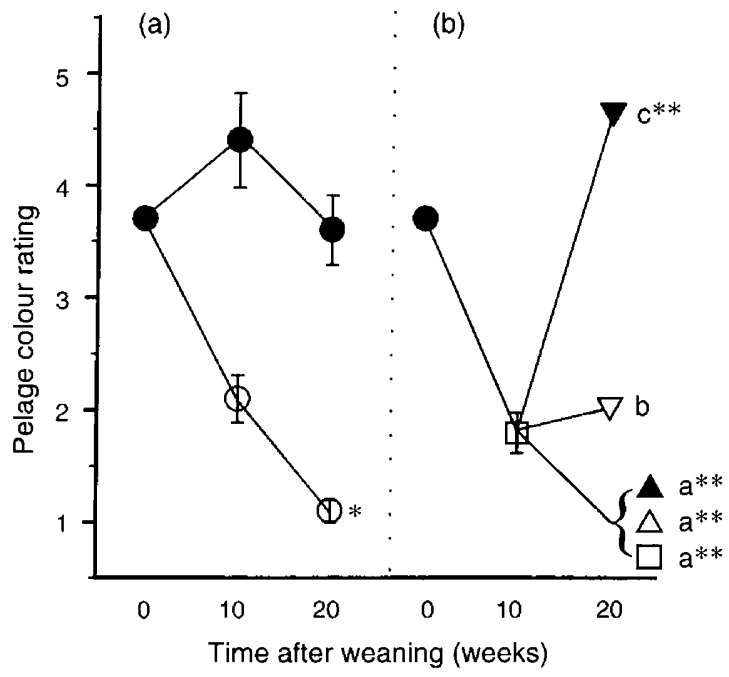

Fig. 5. (a) Pelage colour in collared lemmings born in $8 \mathrm{~h}$ light:16 h dark photoperiod and retained at weaning in (1) $8 \mathrm{~h}$ light:16 h dark photoperiod or transferred to (O) $24 \mathrm{~h}$ light:0 h dark. (b) Pelage colour in collared lemmings born in $8 \mathrm{~h}$ light: $16 \mathrm{~h}$ dark photoperiod and transferred at weaning from (O) $8 \mathrm{~h}$ light:16 h dark to ( $\square$ ) $22 \mathrm{~h}$ light: $2 \mathrm{~h}$ dark. Ten weeks after weaning animals were retained in ( $\square$ ) $22 \mathrm{~h}$ light: $2 \mathrm{~h}$ dark or transferred to $(\triangle) 20 \mathrm{~h}$ light: $4 \mathrm{~h}$ dark, (A) $18 \mathrm{~h}$ light: $6 \mathrm{~h}$ dark, $(\nabla) 16 \mathrm{~h}$ light: $8 \mathrm{~h}$ dark or $(\boldsymbol{\nabla}) 8 \mathrm{~h}$ light:16 h dark. Pelage colour scale: 1 , grey summer pelage; 5 , white winter pelage. * indicates values are significantly different within groups between 10 and 20 weeks. ${ }^{* *}$ indicates values are significantly different from the 10 -week group ( $22 \mathrm{~h}$ light: $2 \mathrm{~h}$ dark, $P<0.05$ ). Different letters indicate significantly different means $(P<0.05)$. Error bars are omitted from $(b)$ for clarity. Pelage colour at week 0 (weaning) estimated from previous data (Gower ef al., 1994). Values are means \pm SEM.

\section{Discussion}

The present experiments suggest that collared lemmings show spontaneous testicular regression following prolonged exposure to photostimulatory long daylength conditions. These data are the first to demonstrate spontaneous testicular regression in a rodent in response to a photoperiod that stimulates reproductive maturation. In addition, the results indicate that constant light, a regimen that does not allow daily melatonin production, has the same effects on testicular growth

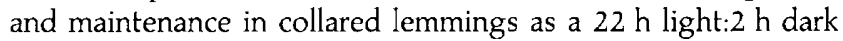
photoperiod under which collared lemmings show a daily melatonin rhythm (Gower et al., 1996).

At 10 weeks animals from the $22 \mathrm{~h}$ light: $2 \mathrm{~h}$ dark and $24 \mathrm{~h}$ light: $0 \mathrm{~h}$ dark groups photoperiods had testes of a size associated with photostimulation (193 $\pm 33 \mathrm{mg}$ ) (Nagy et al., 1993a). However, at 20 weeks animals from these groups had testes that were substantially smaller which suggested that gonadal regression had occurred. Only serial sampling of individuals can show regression definitively. In animals transferred 10 weeks after weaning from $22 \mathrm{~h}$ light: $2 \mathrm{~h}$ dark to $18 \mathrm{~h}$ light: $6 \mathrm{~h}$ dark or $20 \mathrm{~h}$ light: $4 \mathrm{~h}$ dark, the testes and seminal vesicles were maintained at the 10-week mass. Animals transferred to $16 \mathrm{~h}$ light: $8 \mathrm{~h}$ dark showed a slight regression in seminal vesicle mass, but had tissues 20 weeks after weaning that were of greater mass than those of animals remaining in the $22 \mathrm{~h}$ light: $2 \mathrm{~h}$ dark photoperiod. Therefore, transfer to a shorter long photoperiod resulted in maintenance of gonadal size. This observation suggests that a changing photoperiod is critical for interpretation of photic signals.

In the present experiments, animals born in $8 \mathrm{~h}$ light: $16 \mathrm{~h}$ dark and transferred to $22 \mathrm{~h}$ light: $2 \mathrm{~h}$ dark showed apparent testicular regression when subsequently transferred to $8 \mathrm{~h}$ light: $16 \mathrm{~h}$ dark, and those subsequently transferred to $16 \mathrm{~h}$ light: $8 \mathrm{~h}$ dark showed apparent regression of seminal vesicles. Therefore, in addition to showing spontaneous regression of the reproductive system in response to prolonged exposure to a long photoperiod, collared lemmings show reproductive regression in response to a decrease in photoperiod of $6 \mathrm{~h}$ or more. This finding is typical of photoperiodic rodents (Stetson and Watson-Whitmyre, 1986). However, previous studies have failed to detect an inhibitory effect of reduction in daylength on the reproductive axis. Previous reports have indicated that short photoperiods have either a stimulatory effect or no effect. Animals raised in $22 \mathrm{~h}$ light: $2 \mathrm{~h}$ dark and transferred to $8 \mathrm{~h}$ light:16 $\mathrm{h}$ dark developed a greater testicular mass than those that remained in $22 \mathrm{~h}$ light: $2 \mathrm{~h}$ dark (Nagy et al., 1993a), and animals housed in $4 \mathrm{~h}$ light: $20 \mathrm{~h}$ dark had larger seminal vesicles than those housed in $22 \mathrm{~h}$ light: $4 \mathrm{~h}$ dark (Mallory et al., 1986). Transfer of animals raised in $22 \mathrm{~h}$ light: $2 \mathrm{~h}$ dark to $4 \mathrm{~h}$ light:20 h dark (Maier and Feist, 1991), $18 \mathrm{~h}$ light: $6 \mathrm{~h}$ dark to $6 \mathrm{~h}$ light:18 h dark (Hasler et al, 1976), or $16 \mathrm{~h}$ light: $8 \mathrm{~h}$ dark to $8 \mathrm{~h}$ light:16 h dark (Nagy et al., 1993a) had no effect on the rate of testicular maturation (compared with animals remaining in the original photoperiod (Maier and Feist, 1991; Nagy et al., 1993a), or transferred to a longer photoperiod (Hasler et al., 1976)). Discrepancies between these results and the findings of the present study may be due to differences in the photoperiod history of the animals. The present results suggest that only animals in which maximal testicular mass is achieved by transfer from short to long photoperiod will show short day-induced gonadal regression.

Gonadal regression in response to prolonged long day exposure has been described in several avian species. In starlings (Sturnus vulgaris), gonadal growth and reproduction are stimulated by the increase in daylength that occurs after the winter solstice (Nicholls et al., 1988). However, after breeding, reproductive organs rapidly decrease in size. This spontaneous gonadal regression occurs prior to the summer solstice, while the birds are still exposed to long (and increasing) photoperiod (Dawson and Goldsmith, 1982). In these circumstances, starlings display refractoriness to the stimulatory effects of long photoperiod and breeding ceases. Although breeding experiments have not been conducted in male lemmings exposed to chronic long photoperiods, female lemmings are significantly less fecund under these conditions compared with animals subjected to an increase in photoperiod from $8 \mathrm{~h}$ light:16 h dark to $22 \mathrm{~h}$ light: $2 \mathrm{~h}$ dark (B. A. Gower, T. R. Nagy and $\mathrm{M}$. H. Stetson, unpublished). These observations suggest that the response of collared lemmings to prolonged long photoperiods resembles the long day-induced refractoriness of starlings.

Somatic parameters did not show the same response to photoperiodic changes as the reproductive system. Body weight, bifid claw width and pelage colour responded to ambient daylength, regardless of the amount of time the animals were exposed to a given photoperiod. The $22 \mathrm{~h}$ 
light: $2 \mathrm{~h}$ dark groups showed little difference in body weight 10 and 20 weeks after weaning, whereas the groups exposed to a photoperiod reduction showed increments in weight proportional to the decrease in daylength. Similarly, bifid claw size and pelage colour remained as expected for exposure to long daylength, even after prolonged exposure to $22 \mathrm{~h}$ light: $2 \mathrm{~h}$ dark. Pelage colour in collared lemmings may be influenced by serum prolactin (Gower et al., 1993). The moult to white pelage that occurs in response to a decrease in photoperiod is associated with a decrease in prolactin (Nagy et al., 1993b). Prolonged exposure to $22 \mathrm{~h}$ light: $2 \mathrm{~h}$ dark and $24 \mathrm{~h}$ light: $\mathrm{O} \mathrm{h}$ dark is unlikely to be associated with a change in prolactin. This may explain the maintenance of the dark pelage colour in animals that showed spontaneous testicular regression in the present study. Although the physiological mechanisms for the photoperiod-related changes in body weight and bifid claw size are not known, these parameters are not affected by photoperiod history.

The divergent responses of the reproductive and somatic systems to photoperiod in collared lemmings may have a selective basis. Gonadal regression during prolonged exposure to long photoperiod would result in a cessation in breeding at the harshest time of the year for lemmings. Constant light occurs from mid-May to late July, and coincides with the period of snow-melt which causes flooding of lemming habitats (reviewed in Nagy et al., 1995). In addition, the food supply (standing biomass from the previous year) is low and new plant growth has not begun. Therefore, it may be selectively advantageous to interrupt breeding during snow-melt and to reserve resources for times when environmental conditions are more favorable for reproduction. This hypothesis is supported by field data indicating that most reproduction occurs in early spring, a breeding hiatus occurs in late June, and a resumption of breeding is observed in late summer, and autumn and winter. In contrast, changes in body weight, pelage characteristics and claw morphology are likely to have evolved to optimize thermal stability, camouflage and mobility, respectively, during specific times of the year. Therefore, throughout the summer body weight is lower, hair is short and grey, and claws are absent.

In other rodents that show photorefractoriness, somatic parameters change in accordance with gonadal size. In Siberian hamsters, as gonads recrudesce following prolonged and continuous short day exposure, pelage characteristics and body weight also change to long day status (Hoffmann, 1973, 1978). Therefore, the spontaneous testicular regression observed in long day-housed collared lemmings in the present study is quite different from the spontaneous changes observed in other small mammals because changes in somatic characters in lemmings are not coupled to changes in gonad size.

In summary, collared lemmings appear to show spontaneous testicular regression in response to prolonged exposure to photoperiods that initially stimulate gonadal growth $(22 \mathrm{~h}$ light: $2 \mathrm{~h}$ dark and $24 \mathrm{~h}$ light: $0 \mathrm{~h}$ dark). The responses to $22 \mathrm{~h}$ light: $2 \mathrm{~h}$ dark and $24 \mathrm{~h}$ light: $0 \mathrm{~h}$ dark were similar, indicating that the presence of melatonin is not required for sexual maturation or spontaneous testicular regression. Transfer of animals to $8 \mathrm{~h}$ light:16 h dark indicated that short days cause gonadal regression in animals in which testes mass has previously been stimulated to maximal by an increase in photo- period. Therefore, both long and short photoperiods can be either stimulatory or inhibitory to the reproductive axis, depending upon photoperiod history. Unlike the reproductive system, somatic systems responded to the number of light or dark hours per day regardless of photoperiod history, and responded uniquely to a range of different daylengths. These data are in agreement with those of Gower et al. (1992), Nagy (1993) and Nagy et al. (1993a,b) and demonstrate that reproductive and somatic responses to photoperiod are independently regulated in collared lemmings.

This work was supported by NSF grants DCB87-14638 and IBN93-18203 to M. H. Stetson.

\section{References}

Dawson A and Goldsmith AR (1982) Prolactin and gonadotrophin secretion in wild starlings (Sturnus vulgaris) during the annual cycle and in relation to nesting, incubation and rearing of young General and Comparative Endocrinology 48 213-221

Gower BA, Nagy TR and Stetson MH (1992) Role of photoperiod in reproductive maturation and peripubertal hormone concentrations in male collared lemmings, Dicrostonyx groenlandicus. Journal of Reproduction and Fertility 96 153-163

Gower BA, Nagy TR and Stetson MH (1993) Role of prolactin and the gonads in seasonal physiological changes in the collared lemming (Dicrostonyx groenlandicus). The Journal of Experimental Zoology 266 92-101

Gower BA, Nagy TR and Stetson MH (1994) Pre- and postnatal effects of photoperiod on collared lemmings (Dicrostonyx groenlandicus). American Journal of Physiology 267 R879-R887

Gower BA, Nagy TR and Stetson MH (1996) Influence of photoperiod, time and sex on hormone concentrations in collared lemmings (Dicrostonyx groenlandicus). General and Comparative Endocrinology 101 53-62

Gower BA, Nagy TR and Stetson MH (1997) Alteration of testicular response to long photoperiod by transient exposure to short photoperiod in collared lemmings (Dicrostonyx groenlandicus). Journal of Reproduction and Fertility 109 $257-262$

Hasler JF, Buhl AE and Banks EM (1976) The influence of photoperiod on growth and sexual function in male and female collared lemmings (Dicrostonyx groenlandicus). Journal of Reproduction and Fertility 46 323-329

Hoffmann K (1973) The influence of photoperiod and melatonin on testis size, body weight and pelage colour in the Djungarian hamster (Phodopus sungorus). Journal of Comparative Physiology 85 267-282

Hoffmann K (1978) Effect of short photoperiods on puberty, growth and moult in the Djungarian hamster (Phodopus sungorus). Journal of Reproduction and Fertility $\mathbf{5 4} 29-35$

McNaughton FJ, Dawson A and Goldsmith AR (1992) Juvenile photorefractoriness in starlings, Sturnus vulgaris, is not caused by long days after hatching Proceedings of the Royal Society of London 248 123-128

Maier HA and Feist DD (1991) Thermoregulation, growth and reproduction in Alaskan collared lemmings: role of short day and cold American Joumal of Physiology 261 R522-R530

Mallory FF, Brooks RJ and Elliott JR (1986) Variations of skull-body regressions of the lemming (Dicrostonyx groenlandicus) under laboratory and field conditions Zoological Journal of the Linnean Society 87 125-138

Nagy TR (1993) Effects of photoperiod history and temperature on male collared lemmings, Dicrostonyx groenlandicus. Journal of Mammalogy $\mathbf{7 4}$ 990-998

Nagy TR, Gower BA and Stetson MH (1993a) Development of collared lemmings, Dicrostonyx groenlandicus, is influenced by pre- and postweaning photoperiods The Joumal of Experimental Zoology 267 533-542

Nagy TR, Gower BA and Stetson MH (1993b) Threshold photoperiods for the induction of short day traits in the collared lemming (Dicrostonyx groenlandicus). The Joumal of Experimental Zoology 267 57-66

Nagy TR, Gower BA and Stetson MH (1995) Endocrine correlates of seasonal body mass dynamics in the collared lemming (Dicrostonyx groenlandicus). American Zoologist 35 246-258

Nautical Almanac Office (I991) The Astronomical Almanac for the Year 1992 US Government Printing Office, Washington DC 
Nicholls TJ, Goldsmith AR and Dawson A (1988) Photorefractoriness in birds and comparison with mammals Physiological Reviews 68 133-176

Rudeen PK (1977) The Relationship Between Pineal Serotonin N-Acetyltransferase Activity and the Gonadal Status in the Male Albino Rat and Golden Hamster PhD Thesis, University of Texas

Steinlechner S and Niklowitz P (1992) Impact of photoperiod and melatonin on reproduction in small mammals Animal Reproduction Science 30 1-28

Stetson MH and Watson-Whitmyre M (1984) Physiology of the pineal and its hormone melatonin in annual reproduction in rodents. In The Pineal Gland pp 109-153 Ed. RJ Reiter. Raven Press, New York
Stetson MH and Watson-Whitmyre M (1986) Effects of exogenous and endogenous melatonin on gonadal function in hamsters Journal of Neural Transmission $2155-80$

Williams TD, Dawson A and Nicholls TJ (1989) Sexual maturation and moults in juvenile starlings in response to different daylengths Ibis 131 135-140

Zucker I, Johnston PG and Frost D (1980) Comparative, physiological and biochronometric analyses of rodent seasonal reproductive cycles Progress in Reproductive Biology 5 102-133 